\title{
Comparison of horizontal and vertical methods of tooth preparation for a prosthetic crown
}

\author{
PawełŁabno ${ }^{1, A-F}{ }^{\oplus}, K^{\prime}$ rzysztof Drobnik ${ }^{1, A-F \oplus}$ \\ ${ }^{1}$ Outpatient Department for Dental Prosthetics No. 1, Medical University, Łódź, Poland \\ A - Research concept and design, B - Collection and/or assembly of data, C - Data analysis and interpretation, \\ $D$ - Writing the article, E - Critical revision of the article, F - Final approval of article
}

Łabno P, Drobnik K. Comparison of horizontal and vertical methods of teeth preparation for a prosthetic crown. J Pre-Clin Clin Res. 2020; 14(1): 25-28. doi: $10.26444 / j p c c r / 116672$

\begin{abstract}
The application of magnifying devices, such as magnifiers, microscopes, precision drills, intraoral scanners, printed models, milled, and monolithic restorations, increases the precision of the preparation, accuracy of workmanship and marginal tightness, ultimately providing a very high level of quality of prosthetic restoration. The article compares the pros and cons of several types of tooth preparations for different kinds of crowns, including the modern concept of verti prep (vertical preparation).

Tooth preparation for a prosthetic crown is always invasive in character and leads to irreversible loss of tooth hard tissues. In the case of tooth preparation with vital dental pulp there is a risk of its irritation, inflammation, necrosis, and endodontic treatment in the future. A variety of attempts have been made in dental prosthetics to develop the best method of tooth preparation, which - on the one hand - would ensure adequate marginal fit, emergency profile, and at the same time, would lead to the least loss of enamel and dentine ithe preparation process. Current research has confirmed, that there is no single universal and recommended in all cases type of tooth preparation for a prosthetic crown. The choice of a finish line depends on a number of factors, such as pulp vitality, location of the tooth, its inclination, type of material from which a restoration will be manufactured, crown convexity, patient's age and the size of such a construction. It should be emphasized at the same time that in some clinical situations, the decision on the type of preparation and/or reconstruction to be made is taken intra-procedurally.
\end{abstract}

\section{Key words}

dentistry, crowns, prosthetics, marginal fit, finish line, BOPT, fixed restorations, verti prep

\section{INTRODUCTION}

For many years tooth crown preparation with vertical finish lines (knife edge, feather edge) has been a method of treatment by choice due to the applied technique of making Scharp's crowns. The implementation of metal-casting technology made it possible to produce prosthetic crowns on shoulderprep abutments with horizontal finish lines (shoulder and chamfer). It was then possible to compare both methods, and the following drawbacks of vertical preparation were most often noticed: overhangs, uneven edges, biological width disruption, lack of aesthetic appearance, over-contouring, difficulty of determining a finishing line, lack of control on marginal seal and integrity, damage to the epithelial attachment and unpredictable tissue healing, difficulties in removing cement excess, etc. Many disadvantages of vertical finish line made shoulder preparation become acknowledged by the academic world as the gold standard [1]. There is currently a dissonance in everyday practice of a dental prosthetist between preserving red white aesthetics where a significant amount of tooth structure is removed to achieve correct chamfer or shoulder finish line, and planning minimally intensive preparation which requires quite the opposite $[2,3]$.

The application of magnifying device, such as dental loupes, microscope, more common use of precision drills, intraoral scanners, printed models, milled, and monolithic

Address for correspondence: Paweł Łabno, Outpatient Department for Dental Prosthetics No. 1, Medical University, Łódź, Poland

E-mail: stomatologialabno@gmail.com

Received: 08.09.2019; accepted: 17.01.2019; first published:03.03.2020 restorations, increases the precision of preparation, accuracy of workmanship, marginal tightness, and ultimately provides a very high level of quality of prosthetic restoration $[4,5]$.

Tooth preparation for a prosthetic crown is always invasive in character and leads to irreversible loss of tooth hard tissues. In the case of tooth preparation with vital dental pulp there is a risk of its irritation, inflammation, necrosis, and endodontic treatment in the future. A variety of attempts have been made in dental prosthetics to develop the best method of tooth preparation, which - on the one hand - would ensure adequate marginal fit, emergency profile, and on the other hand would lead to the least loss of enamel and dentine in the preparation process [6].

Regardless of the selected type of preparation, tooth preparation is conducted according to the following scheme: lowering of occlusal surface by $1.5 \mathrm{~mm}$ on non-functional cusps and $2.0 \mathrm{~mm}$ on functional cusps, which reflects the future restoration, separation from adjacent teeth, making a crown insertion path on vertical walls, and shoulder preparation $[7,8]$.

The scope of abutment preparation depends on a series of factors, such as: crown convexity, patient's age, vitality of the pulp, degree of inclination, material of the future crown, and size of its structure (single crown or extensive bridge). Taking into consideration the fact that the prepared tooth should be reduced by the size ofthea prosthetic crow, together with the optimal path of its insertion, enamel and a significant part of the dentine is lost during such preparation. Further preparation is required for providing adequate space for the metal and / or ceramics which does not exceed the biological 
width, and which ensures the adequate strength of the material subjected to the occlusal forces $[9,10]$.

The research studies conducted by Sadid-Zadeh et al. indicate that there is no significant statistical difference between the amount of hard tissues lost during the tooth preparation for described types of crowns: complete cast crown (CC), monolithic zirconia crown (MZr), porcelainfused-to-metal crown (PFM), monolithic pressed lithium disilicate crown (MPLD), or monolithic CAD/CAM lithium disilicate crown (MCLD) (Fig. 1) In other words, in a group of horizontal preparation types, loss of tooth structure is versimilar, but one more comparison should be examined - Monolithic Zirconia with edgeless preparation (Fig. 2). Tissues outside the green lines are lost during vertical preparation and those outside of the rethe case of verti prep and shoulder preparation are marked with a blue pattern [11].

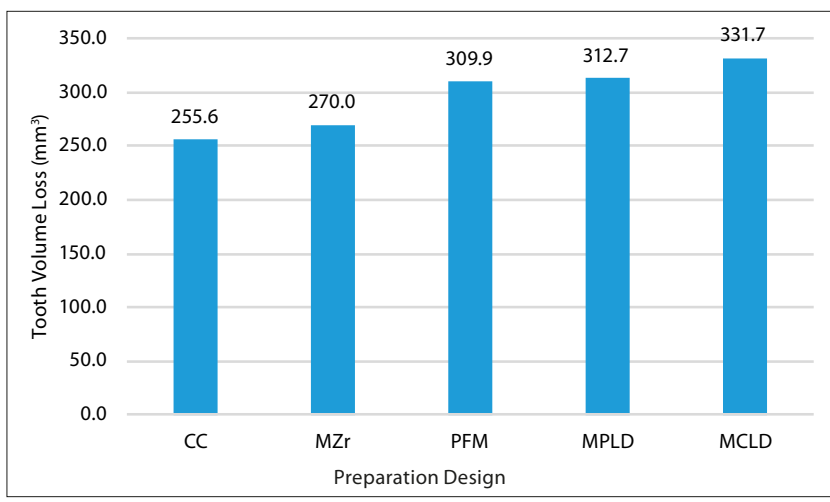

Figure 1. Mean tooth volume loss associated with various complete coverage restorations. CC - complete cast crown; $\mathrm{MZr}$ - monolithic zirconia crown; PFM porcelain fused to metal crown; MPLD - monolithic pressed lithium disilicate crown; MCLD - monolithic CAD/CAM lithium disilicate crown [11]. Adopted with permission

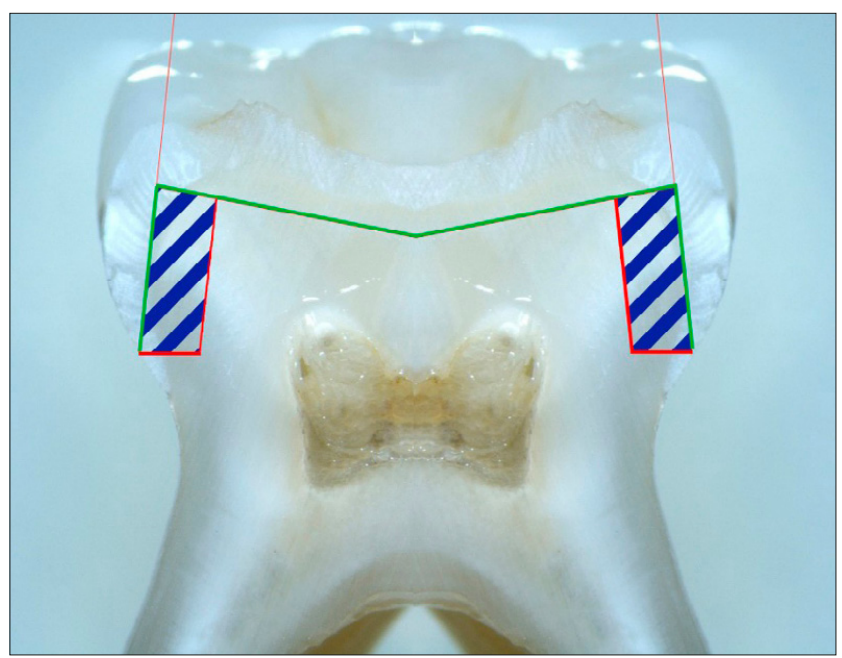

Figure. 2. Difference in range of hard tissues loss in the case of verti prep and shoulder preparation

\section{Types of margin preparation:}

1) vertical preparation:

- edgeless (gingitage, verti prep, no finish line);

- shoulderless (bevel): feather edge / knife edge / chisel edge (rising taper).

2) horizontal preparation:

- straight shoulder-type preparation at $90^{\circ}$ angle (regular shoulder);
- straight shoulder-type preparation at a $90^{\circ}$ angle with a $45^{\circ}$ bevelling (bevelled shoulder);

- rounded shoulder-type preparation at $90^{\circ}$ angle (rounded shoulder);

- straight, rounded shoulder-type preparation with $45^{\circ}$ angle bevelling (bevelled rounded shoulder);

- open chamfer-type preparation (regular chamfer);

- open chamfer-type preparation with $45^{\circ}$ angle inclination (bevelled chamfer).

\section{OBJECTIVE}

The aim of the article is to assess the advantages and disadvantages of various types of tooth preparation applied in the past (shoulderless), considered as a standard at present (shoulder, chamfer), and new solutions (edgeless) still under research but made possible due to the development of modern technologie. PubMed and Google Scholar databases have been used in the search for review articles; summarized results are presented in Table 1.

Horizontal preparation. Numerous authors point out that shoulder $\left(90^{\circ}\right)$ and chamfer $\left(45^{\circ}\right)$ preparations do not differ significantly $[12,13]$. Chamfer-type preparation is recommended in clinical cases where the application of metal restoration is planne, e.g. complete metal cast, PFM (lingual surface), as well as for full-ceramic pressed, cast and milled CAD/CAM restorations due to a lack of volume changes at the sintering stage. Shoulder type preparation can be used for all-ceramic (layered, infiltrated with liquid glass) or PFM (facial surface) restorations, with or without an all-ceramic shoulder. Shoulder type preparation is currently indicated in most cases $[14,15]$.

Vertical preparation - shoulderless. As mentioned above, the shoulderless type of tooth crown preparation (also known as bevel preparation) has been referred to differently according to the rising taper: feather edge, knife edge, chisel edge, but researchers agree that for many years it has been the most conservative approach towards dental structure and the less prone to marginal gap [16]. The historical method was to restore the tooth structure with a Scharp's crown, which was possible even in case of non-parallel preparation thanks to the soft alloy. At present, shoulderless preparation has been practically abandoned due to the application of modern laboratory technologies and to its numerous defects [17].

Vertical preparation - edgeless. The 'rotary gingival curettage' (gingitage, verti prep, edgeless) method, originally developed by Vick Pollard and Rex Ingraham, has been further developed by Di Febo, Carnevale, and more recently by Ignazio Loi [18]. It is also known as the 'biologically oriented preparation technique' (BOPT) and consists in 1) placing the finish line subgingivally, 2) sealing the preparation coronally to the finish line, and 3) shaping the natural edge of an emergence profile above the cemento-enamel junction (CEJ, with the creation of a new prosthetic emergence edge adjacent to the gingival edge (prosthetic cemento-enamel junction / PCEJ). The boundary range of this preparation may be located at different depths of the gingival pocket, depending on the available biological width $[19,20]$.

Adversaries of the method claim that it often results in irreversible damage to the periodontal attachment and 
violates the biological width. Supporters, however, pay attention to using special round-ended 2 degrees tapered diamond burs a non-working tip (batt bur). It has coronal diameter of $1.2 \mathrm{~mm}$, apical diameter of $0.7 \mathrm{~mm}$, and noncutting end of $1 \mathrm{~mm}$, which reduces or avoids damage to the connective attachment and allows a tooth-guided preparation procedure. The length of the non-cutting end and its width should be chosen according to the biological width (BW). Rotary curettage leads to minor bleeding but is limited only to oral sulcular epithelium. According to research results, such new epithelium is thicker and adheres closely to a new prosthetic restoration; however, it is conditioned by manufacturing a very precise, smooth and polished temporary and final reconstruction [21].

An emergency profile of a crown placed on the shoulderless abutment should be smaller than in case of an edgeless abutment, where gingival tissues need a support for predictable growth. This means that the final restoration will be over-contoured by conventional standards [Fig. 3] [21].

Verti prep is indicated in prosthetic restorations where monolithic zirconium oxide crowns are planned and the finish line can be very thin and precise. It can also be used in the case of short teeth, where improved retention can be obtained by a more parallel preparation, in mandibular incisors where creating a shoulder finish line would lead to almost complete removal of the tooth's crown. At present, there are only a small number of clinical research studies regarding this type of preparation. This state of knowledge does not give us the possibility to assess the efficacy of the

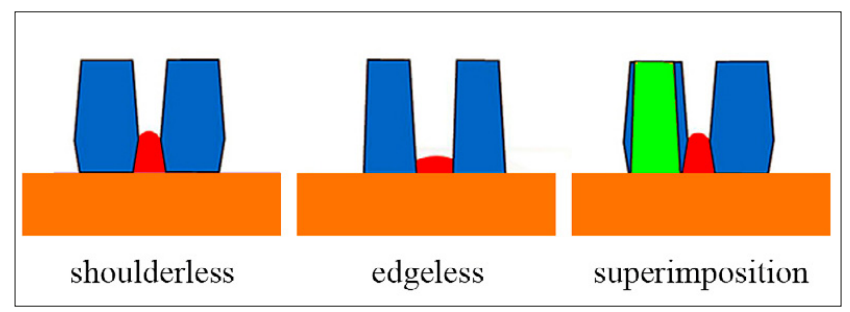

Figure 3. Over-contouring required for a better papilla growth predictability in edgeless preparation [21]. Adopted with permission

method. Therefore, it is necessary to conduct further studies and observations $[22,23,24]$.

\section{CONCLUSIONS}

Current research has confirmed that there is no single universal and recommended method in all cases type of tooth preparation for a prosthetic crown. The choice of a finish line depends on a number of factors, such as pulp vitality, location of the tooth, its inclination, type of material from which a restoration will be manufactured, crown convexity, patient's age, and size of such a construction. At the same time, it should be emphasized that in some clinical situations, such as abutment discoloration or insufficient amount of tooth structures visible after an old crown removal, the decision on the type of preparation and/or reconstruction to be made is taken intra-procedurally.

Table 1. Advantages and disadvantages of different types of preparation

\begin{tabular}{|c|c|c|}
\hline Type of preparation: & Advantages: & Disadvantages: \\
\hline $\begin{array}{l}\text { Horizontal } \\
\text { Preparation }\end{array}$ & $\begin{array}{l}\text { 1. No over-contouring, avoidance of overhangs. } \\
\text { 2. Low risk of porcelain chipping due to limited stress within the cervical } \\
\text { area. } \\
\text { 3. Preservation of biological width. } \\
\text { 4. Preparation depth provides space for colour changes within cervical } \\
\text { area. } \\
\text { 5. Good cooperation with laboratory leads to clear definition of the } \\
\text { margins of preparation and precise determination of its position and } \\
\text { tightness. } \\
\text { 6. Easy elimination of cement excess. } \\
\text { 7. No damage to the epithelial attachment and predictable tissue healing. }\end{array}$ & $\begin{array}{l}\text { 1. High risk of post-operative complications, e.g. hypersensitivity, } \\
\text { inflammation, pulp necrosis, endodontic treatment in the future. } \\
\text { 2. Loss of hard tooth tissue by } 50-60 \% \text {. } \\
\text { 3. Exposure of dentine which facilitates penetration of bacteria in the case } \\
\text { of bacterial micro-leakage. } \\
\text { 4. Lack of marginal seal due to imperfections of technology and } \\
\text { workmanship (marginal gap). } \\
\text { 5. Lack of ferrule (tooth structure removal and stress concentration). } \\
\text { 6. More complicated preparation procedure in relation to vertical } \\
\text { preparation }[25,26] \text {. }\end{array}$ \\
\hline $\begin{array}{l}\text { Vertical Preparation: } \\
\text { Shoulderless }\end{array}$ & $\begin{array}{l}\text { 1. Small loss of tooth hard tissues. } \\
\text { 2. Good marginal seal and integrity. } \\
\text { 3. Preparation mostly within enamel and little within dentine. } \\
\text { 4. Reduced number of post-operative complications, e.g. pain, } \\
\text { hypersensitivity, pulp inflammation, need for endodontic treatment. } \\
\text { 5. Thin layer of ceramics within the cervical area may result in a change } \\
\text { in the colour of its crown. } \\
\text { 6. Ferrule preservation. } \\
\text { 7. Good retention. } \\
\text { 8. Easy tooth preparation. }\end{array}$ & $\begin{array}{l}\text { 1. Unaesthetic (thin, opaque porcelain layer in cervical area). } \\
\text { 2. Present overhangs, uneven edges. } \\
\text { 3. Causing damage to the epithelial attachment and unpredictable tissue } \\
\text { healing. } \\
\text { 4. Waiting time for tissue healing at the stage of temporary restorations } \\
-6 \text { weeks. } \\
\text { 5. Porcelain chipping due to stress within the cervical area. } \\
\text { 6. No control on marginal seal and integrity. } \\
\text { 7. Biological width disruption., } \\
\text { 8. Not possible to assess the final fit of a crown. } \\
\text { 9. Difficult cooperation with laboratory, especially in terms of providing } \\
\text { information on the proper range of prosthetic restoration. } \\
\text { 10. Difficulties in removing cement excess [ } 27-29] \text {. }\end{array}$ \\
\hline $\begin{array}{l}\text { Vertical Preparation } \\
\text { - Edgeless }\end{array}$ & $\begin{array}{l}\text { 1. Small loss of tooth hard tissues. } \\
\text { 2. Preparation mostly within enamel and little within dentine, which } \\
\text { provides protection for remaining part of the tooth, consequently } \\
\text { reducing pain thanks to the possibility of conducting preparation } \\
\text { without anaesthesia. } \\
\text { 3. Reduction of post-operative complications, e.g. pain, hypersensitivity, } \\
\text { pulp inflammation and necrosis. } \\
\text { 4. Low risk of creating a marginal gap. } \\
\text { 5. No damage to epithelial attachment; predictable tissue healing. } \\
\text { 6. Ferrule preservation. } \\
\text { 7. High friction due to low wall convergence. }\end{array}$ & $\begin{array}{l}\text { 1. Demanding work due to the applied instrumentation: operational } \\
\text { microscope, intraoral scanner, dental model printer. } \\
\text { 2. High level of difficulty of clinical operations. } \\
\text { 3. Quite narrow range of application at the moment; zirconium-oxide } \\
\text { based restorations. } \\
\text { 4. Difficulties in removing cement excess. } \\
\text { 5. No control on marginal seal and integrity. } \\
\text { 6. Not possible to assess the final fit of a crown, } \\
\text { 7. wWiting time for tissue healing at the stage of temporary restorations } \\
-2 \text { weeks. } \\
\text { 8. Sall number of prospective clinical research studies assessing the } \\
\text { efficacy of this method [30-32]. }\end{array}$ \\
\hline
\end{tabular}


In spite of the intensive development of technology, both with reference to clinical tooth preparations for permanent restorations and to laboratory technologies, the range of indications for the application of verti prep is minor, and at present is limited to restorations made only of full-contour zirconium oxide. Due to the small number of clinical studies undertaken to assess the efficacy of this method of preparation, it is necessary to conduct further research studies and observations.

\section{REFERENCES}

1. Shillingburg HT, Hobo S, Fisher DW. Preparation design and margin distortion in porcelain-fused-to-metal restorations. J Prosthet Dent. 2003. doi: 10.1016/S0022-3913(03)00239-7

2.Edelhoff D, Sorensen JA. Tooth structure removal associated with various preparation designs for anterior teeth. J Prosthet Dent. 2002. doi: $10.1067 / \mathrm{mpr} .2002 .124094$

3. Asavapanumas C, Leevailoj C. The influence of finish line curvature on the marginal gap width of ceramic copings. J Prosthet Dent. 2013; 109(4): 227-233. doi: 10.1016/S0022-3913(13)60049-9

4. Tao J, Han D. The effect of finish line curvature on marginal fit of all-ceramic CAD/CAM crowns and metal-ceramic crowns Quintessence Int. 2009; 40(9): 745-752. http://www.ncbi.nlm.nih.gov/ pubmed/19862401. Accessed July 9, 2018.

5. Valenti M, Valenti A. Retrospective survival analysis of 110 lithium disilicate crowns with feather-edge marginal preparation. Int J Esthet Dent. 2015; 10(2): 246-257. http://www.ncbi.nlm.nih.gov/ pubmed/25874272. Accessed July 9, 2018.

6. Tripathi S, Amarnath GS, Muddugangadhar BC, Sharma A, Choudhary S. Effect of Preparation Taper, Height and Marginal Design Under Varying Occlusal Loading Conditions on Cement Lute Stress: A Three Dimensional Finite Element Analysis. J Indian Prosthodont Soc. 2014; 14(S1): 110-118. doi: 10.1007/s13191-014-0378-7

7. Contrepois M, Soenen A, Bartala M, Laviole O. Marginal adaptation of ceramic crowns: A systematic review. J Prosthet Dent. 2013; 110(6): 447-454. e10. doi: 10.1016/j.prosdent.2013.08.003

8. Vigolo P, Mutinelli S, Biscaro L, Stellini E. An In Vivo Evaluation of the Fit of Zirconium-Oxide Based, Ceramic Single Crowns with Vertical and Horizontal Finish Line Preparations. J Prosthodont. 2015; 24(8): 603-609. doi: 10.1111/jopr.12340

9. Aboushelib MN. Fatigue and Fracture Resistance of Zirconia Crowns Prepared with Different Finish Line Designs. J Prosthodont. 2012. doi: 10.1111/j.1532-849X.2011.00787.x

10. Schmitz JH, Cortellini D, Granata S, Valenti M. Monolithic lithium disilicate complete single crowns with feather-edge preparation design in the posterior region: A multicentric retrospective study up to 12 years. Quintessence Int (Berl). 2017. doi: 10.3290/j.qi.a38678

11. Sadid-Zadeh R, Farsaii A, Goodarzi A, Davis EL. Loss of tooth structure associated with preparation for two monolithic CAD-CAM complete coverage restorations. J Prosthet Dent. 2018; 120(3): 403-408. doi: 10.1016/J.PROSDENT.2017.12.018

12. Vaswani PL, Sanyal PK, Gosavi SY, Kore AR. An In-vitro Comparative Stereomicroscopic Analysis and Evaluation of Marginal Accuracy in Porcelain Fused to Metal Copings Fabricated in Two Different Finish Lines Using Variant Die Materials. J Clin DIAGNOSTIC Res. 2017; 11(1): ZC01-ZC05. doi: 10.7860/JCDR/2017/21370.9131

13. Subasi G, Ozturk N, Inan O, Bozogullari N. Evaluation of marginal fit of two allceramic copings with two Finish lines. Eur J Dent. 2012. doi: 10.1055/s-0039-1698946

14. Syu JZ, Byrne G, Land MF, Laub LW. Influence of finish-line geometry on the fit of crowns. Int J Prosthodont. 1993.
15. Goodacre CJ, Campagni W V., Aquilino SA. Tooth preparations for complete crowns: An art form based on scientific principles. J Prosthet Dent. 2001. doi: 10.1067/mpr.2001.114685

16. Limkangwalmongkol P, Chiche GJ, Blatz MB. Precision of fit of two margin designs for metal-ceramic crowns: Basic science research. J Prosthodont. 2007. doi: 10.1111/j.1532-849X.2007.00186.x

17. Piemjai M. Effect of Seating Force, Margin Design, and Cement on Marginal Seal and Retention of Complete Metal Crowns. Int J Prosthodont. 2001.

18. Loi I, Di Felice A. Biologically oriented preparation technique (BOPT): a new approach for prosthetic restoration of periodontically healthy teeth. Eur J Esthet Dent. 2013; 8(1): 10-23. http://www.ncbi.nlm.nih. gov/pubmed/23390618. Accessed July 9, 2018.

19. Lang NP, Kiel RA, Anderhalden K. Clinical and microbiological effects of subgingival restorations with overhanging or clinically perfect margins. J Clin Periodontol. 1983. doi: 10.1111/j.1600-051X.1983.tb01295.x

20. Comlekoglu M, Dundar M, Özcan M, Gungor M, Gokce B, Artunc C. Influence of Cervical Finish Line Type on the Marginal Adaptation of Zirconia Ceramic Crowns. Oper Dent. 2009; 34(5): 586-592. doi: $10.2341 / 08-076-\mathrm{L}$

21. Magallanes Ramos R, Clark D, Mazza M, Venuti P, Maiolino M, Kopanja S, Cirimpei V, TawfikAA, BordonaliD, AcatrineiB, SutradharJC, Czerwinski M, A Sienkiewicz JK. The Shoulderless Approach A New Rationale in Prosthetic Dentistry. Tomorrow Tooth Journal. https:// zeroinon.it/it/articles/the-shoulderless-approach-a-new-rationalein-prosthetic-dentistry-brsmallrmagallanes-ramos-dclark-mmazzapvenuti-mmaiolino-skopanja-vcirimpei-aatawfik-dbordonalibacatrinei-jcsutradhar-mczerwinski-asienkiewicz-jkhademi. Published 2017. Accessed November 20, 2019.

22. Euán R, Figueras-Álvarez $\mathrm{O}$, Cabratosa-Termes J, Brufau-de Barberà M, Gomes-Azevedo S. Comparison of the Marginal Adaptation of Zirconium Dioxide Crowns in Preparations with Two Different Finish Lines. J Prosthodont. 2012. doi: 10.1111/j.1532-849X.2011.00831.x

23. Rashid Habib S, Ginan Al Ajmi M, Al Dhafyan M, Jomah A, Abualsaud $\mathrm{H}$, Almashali M. Effect of Margin Designs on the Marginal Adaptation of Zirconia Copings. Acta Stomatol Croat. 2017; 51(3): 179-187. doi: 10.15644/asc51/3/1

24. Mitov G, Anastassova-Yoshida Y, Nothdurft FP, Von See C, Pospiech P. Influence of the preparation design and artificial aging on the fracture resistance of monolithic zirconia crowns. J Adv Prosthodont. 2016. doi: 10.4047/jap.2016.8.1.30

25. Ichim I, Kuzmanovic DV, Love RM. A finite element analysis of ferrule design on restoration resistance and distribution of stress within a root. Int Endod J. 2006. doi: 10.1111/j.1365-2591.2006.01085.x

26. Viverito JA. The porcelain-faced, cast, shoulderless jacket crown. KOKUBYO-GAKKAI-ZASSHI. 1930.doi: 10.5357/koubyou1927.4.2_120

27. Smith GP. The marginal fit of the full cast shoulderless crown. J Prosthet Dent. 1957. doi: 10.1016/0022-3913(57)90079-3

28. Vojdani M, Safari A, Mohaghegh M, Pardis S, Mahdavi F. The effect of porcelain firing and type of finish line on the marginal fit of zirconia copings. J Dent (Shiraz, Iran). 2015.

29. Paniz G, Nart J, Gobbato L, et al. Clinical Periodontal Response to Anterior All-Ceramic Crowns with Either Chamfer or Feather-edge Subgingival Tooth Preparations: Six-Month Results and Patient Perception. Int J Periodontics Restorative Dent. 2017. doi: 10.11607/ prd.2765

30. Agustín-Panadero R, Solá-Ruíz MF. Vertical preparation for fixed prosthesis rehabilitation in the anterior sector. J Prosthet Dent. 2015; 114(4): 474-478. doi: 10.1016/j.prosdent.2015.05.010

31. Imburgia M, Canale A, Cortellini D, Maneschi M, Martucci C, Valenti M. Minimally invasive vertical preparation design for ceramic veneers. Int J Esthet Dent. 2016.

32. Agustín-Panadero R, Solá-Ruíz MF, Chust C, Ferreiroa A. Fixed dental prostheses with vertical tooth preparations without finish lines: A report of two patients. J Prosthet Dent. 2016. doi: 10.1016/j.prosdent.2015.11.011 